\title{
Prenatally Diagnosed Infantile Myofibroma of Sartorius Muscle-A Differential for Soft Tissue Masses in Early Infancy
}

\author{
Ștefan Popa ${ }^{1,2}$, Dan Apostol ${ }^{2}$, Ovidiu Bîcă ${ }^{2,3}$, Diana Benchia ${ }^{2,4}$, Ioan Sârbu ${ }^{2,4, *(1)}$ and Carmen Iulia Ciongradi ${ }^{2,4}$ \\ 1 3rd Department of Medical Specialities-Legal Medicine, “Grigore T. Popa” University of Medicine and \\ Pharmacy Iași, 700115 Iași, Romania; dr_popastefan@yahoo.com \\ 2 "Sfânta Maria" Emergency Children Hospital Iași, 700309 Iași, Romania; dan12apostol@yahoo.com (D.A.); \\ ovidiubica.d@gmail.com (O.B.); diana_benchia@yahoo.com (D.B.); iuliaciongradi@yahoo.com (C.I.C.) \\ 3 2nd Department of Morphofunctional Sciences-Cell and Molecular Biology, \\ "Grigore T. Popa" University of Medicine and Pharmacy Iași, 700115 Iași, Romania \\ 4 2nd Department of Surgery-Pediatric Surgery and Orthopedics, \\ "Grigore T. Popa" University of Medicine and Pharmacy Iași, 700115 Iași, Romania \\ * Correspondence: dr.sarbu@gmail.com; Tel.: +40-745-760-716
}

Citation: Popa, Ș.; Apostol, D.; Bîcă, O.; Benchia, D.; Sârbu, I.; Ciongradi, C.I. Prenatally Diagnosed Infantile Myofibroma of Sartorius Muscle-A Differential for Soft Tissue Masses in Early Infancy. Diagnostics 2022, 11, 2389. https://doi.org/ 10.3390/diagnostics11122389

Academic Editor: Edward J. Pavlik

Received: 5 November 2021

Accepted: 11 December 2021

Published: 18 December 2021

Publisher's Note: MDPI stays neutral with regard to jurisdictional claims in published maps and institutional affiliations.

Copyright: (C) 2021 by the authors Licensee MDPI, Basel, Switzerland. This article is an open access article distributed under the terms and conditions of the Creative Commons Attribution (CC BY) license (https:// creativecommons.org/licenses/by/ $4.0 /)$.

\begin{abstract}
Background: Infantile myofibromatosis (IM) is a soft tissue disease with solitary or multiple benign tumors, and an etiology still unknown. IM is a mesenchymal disorder of early infancy and is more frequent in males. IM may present as a solitary lesion of the skin, bone, muscle, subcutaneous tissue, located at the head, neck, and trunk, with good prognosis; or, as a multicentric form, with or without visceral involvement (heart, lung, gastrointestinal tract, kidney), with a poor prognosis. The definitive diagnosis of IM is confirmed by pathology. Treatment may be conservative, surgical, or chemotherapeutical. Case presentation: A two months old female patient, prenatally diagnosed at 30 weeks, presenting with a tumor on the antero-internal aspect of the left thigh. She was admitted due to rapid postnatal evolution, and the patient required surgery for tumor resection. Previously, clinically, biological and imaging investigations were performed, but the final diagnosis was histological and by immunostaining. The patient had a favorable postoperative outcome. Conclusions: Despite its low frequency, IM should be considered in the differential diagnosis of soft tissue masses at an early age. The clinical form (solitary or multicentric), location, and visceral involvement will dictate the treatment and prognosis.
\end{abstract}

Keywords: infantile myofibromatosis; lower limb tumor; thigh tumor; prenatal diagnose

\section{Introduction}

Infantile myofibromatosis (IM) manifests as a single or multicentric lesion of benign nature [1]. The incidence of the disease is low, although it is considered the most common type of mesenchymal tumor during infancy and early childhood, with an unknown etiology [2]. Sporadic presentation is more common in children $<2$ years.

This article describes a case of a 2 months old girl who was detected with a left thigh mass on the prenatal ultrasound at 30 weeks of gestation; she was presented for consultation due to the presence and rapid growth of the tumor. The aim of this article is to present the clinical case, its management and to review the literature on this disease.

\section{Case Report}

We report the case of a 2 months old female, presented for consultation due to the presence of a lump on her left thigh, with progressive and constant growth after birth. The lesion was first described on the prenatal ultrasound at 30 weeks of gestation as a pre-femoral soft tissue mass of $20 / 7 \mathrm{~mm}$ (Figure 1). The patient was delivered by cesarean section due to fetal distress but was otherwise normal at birth. Development was normal, and there was no relevant family history. On clinical examination, there was a 25/10 mm 
nodule on the antero-intern side of the left thigh that was firm, mobile and within the deep layers. The overlying skin was normal. There were no other lesions elsewhere on the patient's body.
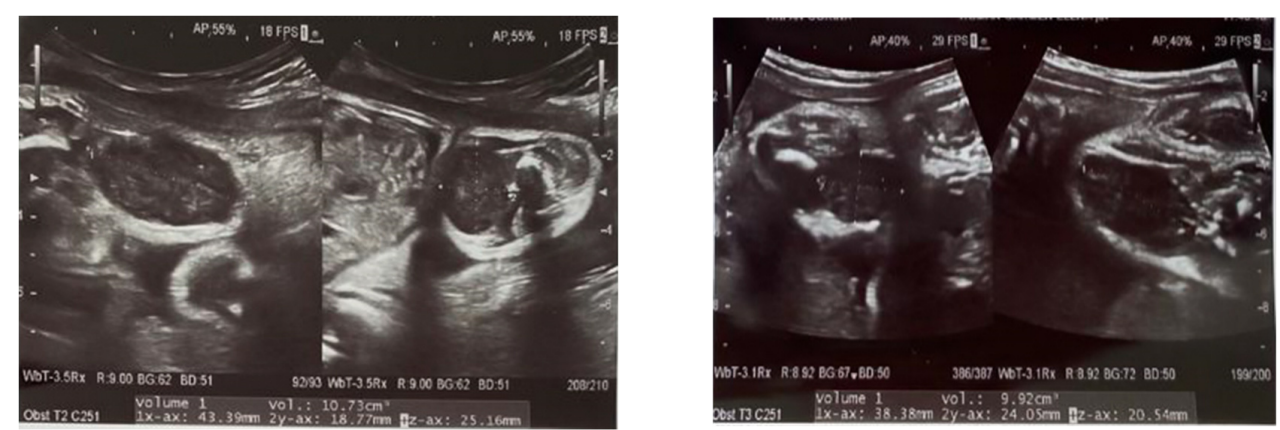

Figure 1. Prenatal ultrasound images at 30 weeks of gestation, showing an oval mass, hypoechoic with calcification on the thigh, with no evidence of bone involvement.

The initial X-ray and ultrasound (US) showed a pre-femoral soft tissue mass that measured approximately $30 / 13 \mathrm{~mm}$, with nonhomogeneous structure, hypoechoic areas, calcifications, and weak Doppler signal, being located anteriorly to the vascular elements of the thigh (Figure 2A). Abdominal ultrasound was normal.
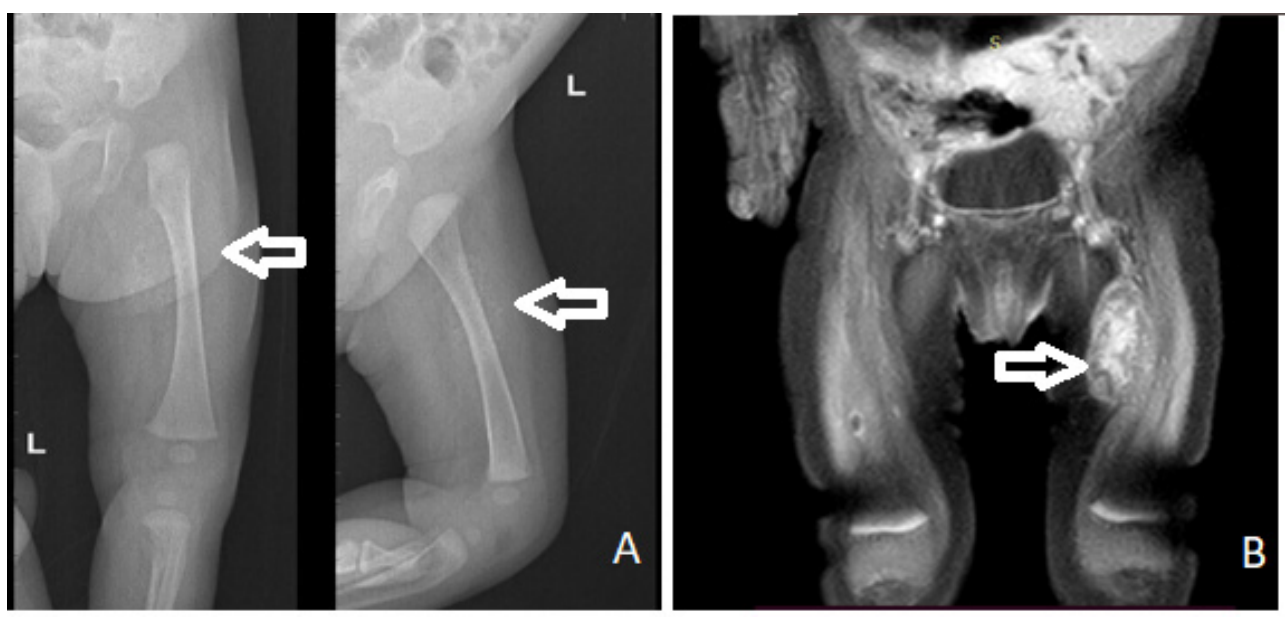

Figure 2. X-ray (A) and MRI (B) showing a mass on the antero-intern part of the left thigh (arrow).

Magnetic resonance imaging (MRI) showed a mass of 19.33/15.19/34 mm, with a nonspecific vascular involvement (Figure 2B). In T1-weighted images, the MRI appearance consisted of a low signal. In T2-weighted fat-saturated images, a high signal intensity of the lesion was shown with nonhomogeneous contrast setting after intravascular contrast was administered, but with late homogenization, located on the antero-internal part of the left thigh with an important mass effect on the left vastus intermedius muscle. The lesion was considered to be probably a schwanoma of the left saphenous nerve.

Elective surgery was scheduled. An italic S-shaped incision on the antero-internal face of the left thigh was performed, from the crural arch distally extended for about $6 \mathrm{~cm}$. A mass of approximately $4 \mathrm{~cm} \times 1.5 \mathrm{~cm} \times 1.5 \mathrm{~cm}$ was revealed, which included the entire thickness of the sartorius muscle (Figure $3 \mathrm{~A}, \mathrm{~B}$ ). In the $1 / 3$ medial part of the tumor, dissection was performed, isolating it from the femoral vasculo-nervous package without opening the sheath of the vasculo-nervous canal. The sartorius muscle was resected at a distance of about $2 \mathrm{~cm}$ distal and proximal to the tumor, with complete tumor resection (Figure 3C). Hemostasis was performed and adjacent tissue approximated. The excised mass was sent for pathological analysis. The patient had a favorable surgical outcome and 
was discharged 3 days postoperatively. At one year after surgery follow up, the child had no recurrence.
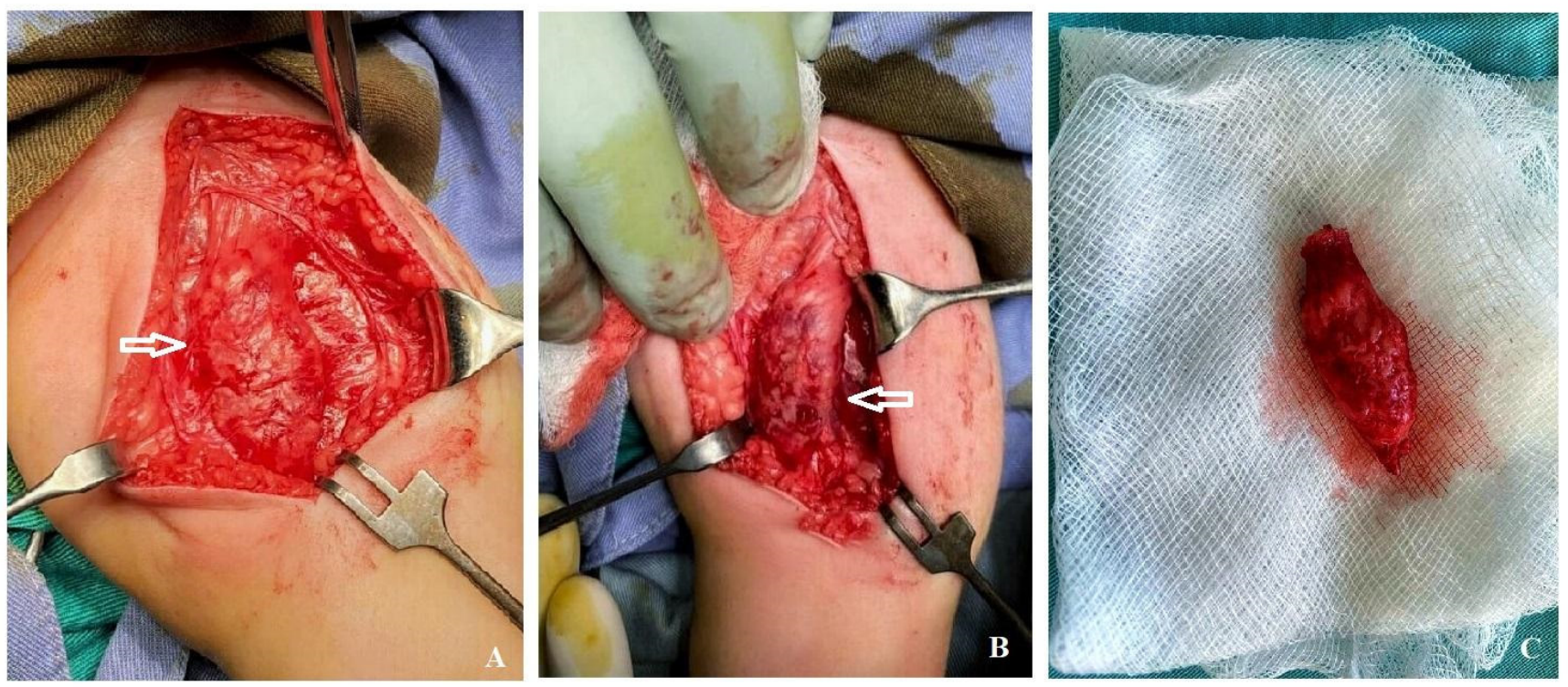

Figure 3. (A) Intraoperative aspect of the tumor. Note that the lesion includes the entire thickness of the sartorius muscle (arrow). (B) Tumor in the crural fascia that highlights an approximately $4 \mathrm{~cm} \times 1.5 \mathrm{~cm} \times 1.5 \mathrm{~cm}$ lesion which includes the entire thickness of the sartorius muscle (arrow). (C) Sartorius muscle resected at a distance of about $2 \mathrm{~cm}$ distal and proximal to the tumor, with complete tumor resection.

Histologically, the mass in the sartorius muscle was noted as a proliferation of tapered cells arranged in an irregular spiral pattern and crossed by thin-walled vessels. In the central region, biphasic proliferation consisting of nodules with necrosis and central calcifications was observed, and between the nodules, fusiform cell proliferates arranged in small intersecting bundles (Figure $4 \mathrm{~A}, \mathrm{~B}$ ). Occasional micronuclei were evident. A pseudocapsule formed by a thin layer of connective tissue $<1 \mathrm{~mm}$ covered the mass. Neoplastic proliferation encompassed residual skeletal muscle fibers in the center of the lesion. Extracapsular and peripheral scarce mature adipose tissue were seen with isolated large-caliber blood vessels. Immunostaining revealed the following results: vimentin positive, smooth muscle actin positive in nodules with necrosis and calcifications (miotic nodules), desmin focal positive, Ki67 low (about 5 positive cells per 100 tumor cells, suggesting low cell kinetics) (Figure 4D-F).

Diagnosis of IM of left sartorius muscle was made. 


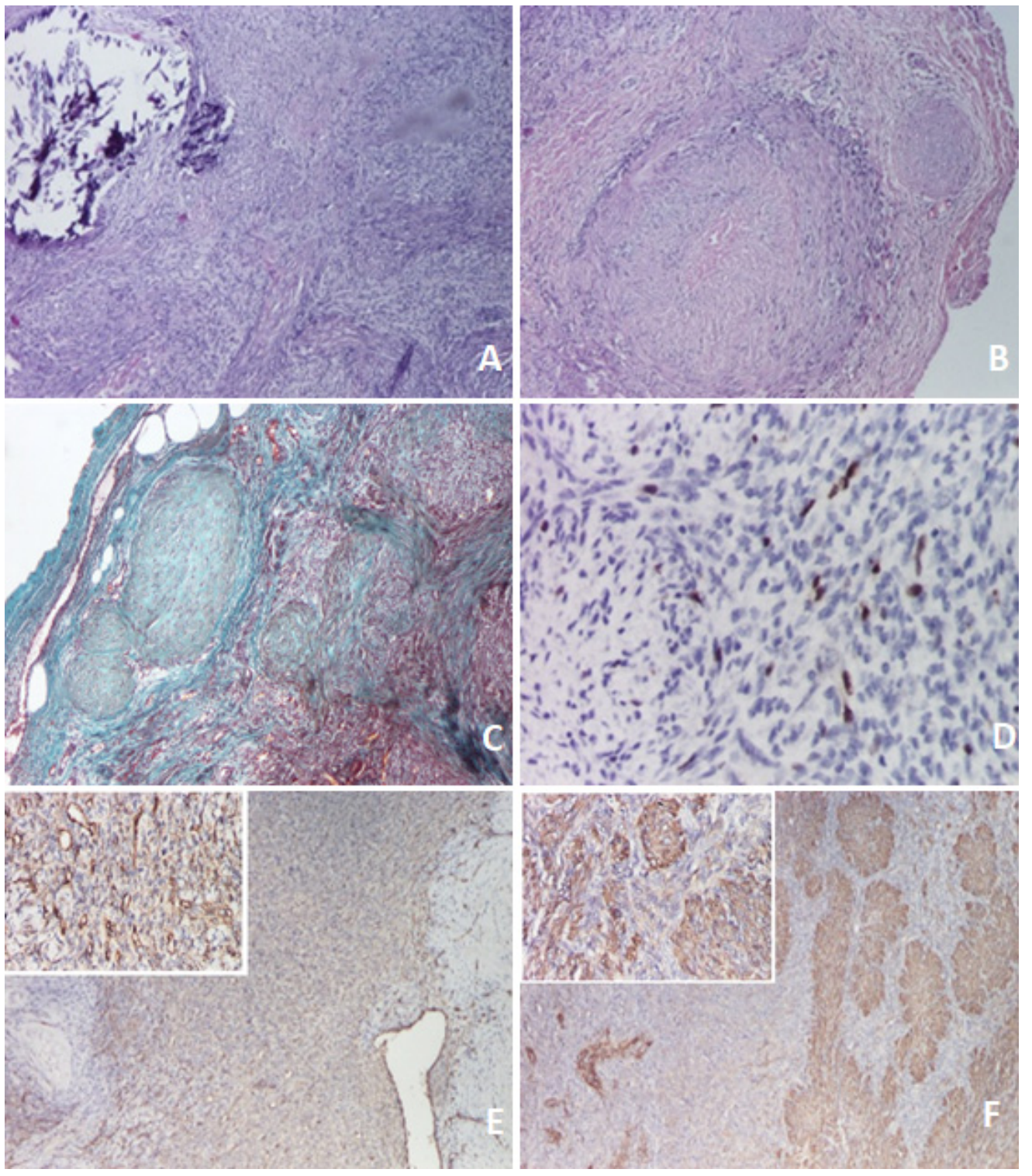

Figure 4. Hemathoxilin eosine staining $(\times 40)$ : (A) Multiple fusiform cells, arranged in fascicle and nodules. (B) Node with central necrosis. Trichromic Szekely stain $(\times 40)$ : (C) Biphasic aspect. Immunochemistry: (D) Ki67 + in about 5\% of the tumor $(\times 200)$. (E) CD34-vascular hemangiopericytoma-like proliferation $(\times 40 / \times 200)$. (F) Smooth muscle actin stain miotic nodule $(\times 40 / \times 200)$.

\section{Discussion-Literature Review}

Infantile myofibroma/myofibromatosis is a rare but well recognized spindle cell neoplasm, a mesenchymal disorder caused by the fibrous proliferation in the skin, bone, muscle, and viscera [3].

Defined as a rare disease by the National Organization for Rare Disorders (NORD) and Orphanet, with an estimated incidence of 1/150,000 to 1/400,000, IM is the most common fibrous tumor in infancy and childhood [4,5].

IM was first described in 1951 as "congenital fibrosarcoma" by Williams and Schrum. Then, in 1954, Stout called it "generalized congenital fibromatosis", suggesting a multicentric benign fibroblastic process [6]. Since this paper, other cases have been reported in the literature under different names, such as multiple hamartomas, multiple vascular leiomyomatosis of the newborn, and multiple congenital fibromatosis. In 1965, Kauffman and Stout defined two forms: one involving skin, subcutaneous tissue, or skeleton, without visceral involvement, having a good prognosis; another type, affecting soft tissue, muscles, 
bones, and internal organs, with poor prognosis [7]. In 1981, a study was conducted by Chung and Enzinger to review the cases reported so far and determine certain features of the disease that remain in place [8]. The authors changed the name from congenital generalized fibromatosis (CGF) to "infantile myofibromatosis" and also established the cell lines from which the lesion appeared and defined the differences in prognosis with the location and involvement, solitary or multicenter, with or without visceral compromise [8]. Finally, in 1989, Smith et al. and Daimaru et al. coined the terms "myofibromas" and "myofibromatosis", nomenclature adopted by the World Health Organization (WHO) to describe solitary form (myofibroma) or multicenter form (myofibromatosis) [9,10].

Infantile myofibromatosis (IM) has a male predominance of $1.7 / 1$ and low incidence. As the lesions may not be clinically visible and involute spontaneously, the condition may be underdiagnosed and underreported. The lesions can appear over a wide age range, but generally manifest in infancy, half of them being diagnosed at birth; about $90 \%$ of cases are diagnosed before the age of 2 years [3,5].

The etiology of the disease is still unknown, the majority of the cases reported being sporadic and isolated; there seems to be a familial pattern suggesting an autosomal dominant or recessive trait $[11,12]$. In the later years, two genes have been identified as causing the disease: PDGFRB and NOTCH3. Mutation in the receptor of the platelet derived growth factor (PDGFRB), a tyrosine kinase receptor, are mitogens for cells of mesenchymal origin. The process is regulated by NOTCH3 [12]. Cytogenetic and fluorescence in situ hybridization analyses showed a pseudodiploid karyotype with an interstitial deletion of the long arm of chromosome 6, del (26) (12q15q), which was the sole anomaly found thus far [13].

Prenatal diagnosis of an IM was first reported in 1998 by Kubota et al., describing a lesion of the triceps detected at 36 weeks of gestation [14]. As with all soft tissue lesions, IM can be diagnosed during pregnancy, the optimal time for detection being between 30 and 32 weeks; even so, the majority of the cases were diagnosed later during pregnancy (36-38 weeks of gestation). A careful prenatal US examination in the second part of the gestation is generally able to detect this type of lesion, but there are also reports of utilizing fetal MRI for a better definition of the abnormal tissue, to assess the extent and to exclude multicentric visceral forms. The prenatal imaging findings are not pathognomonic, but MRI is superior in differentiating fibrosarcoma. Generally, IM was reported in the literature as having prenatal diagnosis with visceral involvement, in which case, if the lesions were multiple and involved important viscera, pregnancy termination could be an option [14-19]. Our case was recognized as a soft tissue tumor relatively early in the pregnancy and well described as a unique tumor, with a less frequent localization of IM.

Clinically, a firm or hard nodule in the skin, subcutaneous tissue, muscle, or bone is defined as the solitary form, which is the most common (50-75\% of cases), as noted by Chung and Muraoka, being the form of presentation in our patient $[8,20]$. The single nodules of myofibroma are usually well circumscribed, with an initial phase of rapid growth, and painless [9]. It mainly affects the regions of the head, neck, and torso. In the case presented, it had localization at the lower limb in a female patient, which is type that is much more common in males, especially in the upper part of the body.

Multiple lesions define the multicentric form, with or without visceral involvement. The multicentric form usually presents at birth and the solitary form may present later, usually in the first 2 years of life $[5,21]$. Wiswell reported that $37 \%$ of multicentric localization had visceral involvement [22].

Imaging is not pathognomonic but serves to assess the degree of disease (especially in multifocal forms), disease progression, and diagnosis of recurrences [15]. The ultrasound examination can reveal a hyperechoic or anechoic center with a surrounding ring, and offers information about the stiffness, encapsulation, liquefaction, calcification, and blood flow. In soft tissue tumors, CT exam will show isodense or less dense than muscle, with defining characteristics such as peripheral enhancement and calcifications; in forms with bone involvement, the image will be similar to the radiographically aspects, showing well 
defined osteolytic lesions with sclerotic rings. MRI reveals mass with low signal center and peripheral rim enhancement on T1-weighted [23].

The differential diagnoses for soft tissue masses includes neurofibroma, sarcoma, metastatic neuroblastoma, and other neoplasms (like congenital childhood fibrosarcoma and inflammatory myofibroblastic tumor), dermoid or epidermoid tumors. Histological examination of biopsies or resected tumors remains the gold standard method for diagnosis [24].

Microscopically, both the solitary and multicentric forms have similar characteristic appearances with a distinct zoning pattern. There are spindle cells arranged in whorled or interlacing fascicles, giving a leiomyoma-like appearance in the peripheral areas of nodular lesions. The constitutive spindle cells demonstrate staining characteristics of both myoblasts and fibroblasts, and frequently contain a large quantity of collagen within the surrounding matrix. In the central areas, a hemangiopericytoma-like pattern consisting of cells with less differentiation is usually found. A high mitotic rate with the presence of up to as many as 3 mitotic figures per 10 high-power field and infiltration of adjacent adipose tissue and skeletal muscle are not unusual, but have no adverse prognostic significance $[8,22,25,26]$. As in our case, biphasic tumor proliferation consisting of nodules with necrosis and central calcifications, and between the nodules, a fusiform cell-proliferate arranged in small intersecting bundles, were the main feature.

The prognosis and natural evolution depend on the type of IM. Spontaneous regression may occur in solitary cases and also may be observed in most of the multicentric cases, within 18 to 24 months. In this scenario, careful follow-up must be done, as recurrences after regressions may occur [22]. Chung et al. reported a 7\% recurrence rate [4]. Massive apoptosis has been suggested as a mechanism of tumor regression [26].

The treatment should be individualized, as there are no standard protocols or guidelines because of the rarity of the disease. The interventions, procedures and therapeutics are variable according to the number, size, location, symptoms, and evolutive pattern of IM.

Solitary lesions or multiple lesions in infants, in the absence of visceral involvement, usually have a benign and self-limited course that ends with spontaneous regression. If the tumor size increases significantly in a short time or if it produces compression to surrounding structures, surgical removal may be considered. The recurrence rate after excision in the solitary form is less than $10 \%[22,27]$. In the case presented, the rapid and constant growth of the lesion before and after birth, along with the particular characteristics (prenatal diagnosis, female, lower limb mass, and muscle localization), and the schwanomalike appearance at MRI dictated surgical excision.

In cases of persistent nodules or recurrence and in forms with visceral involvement when surgery was not possible, chemotherapy, radiation, and steroid therapy have been tried for treatment of IM [28,29]. In addition, subcutaneous interferon alfa ( 3 million $\mathrm{U} / \mathrm{m}^{2}$ daily) for 2 months was the treatment in a Turner's syndrome patient with IM, which resulted in a decrease in size and apoptosis on histological examination [30].

A connection between the p.R561C mutation in gene encoding platelet-derived growth factor receptor beta (PDGFR-beta) and the development of infantile myofibromatosis, was confirmed by recent studies, raising the idea that PDGFR-beta phosphorylation in tumor cells may be reduced by the receptor tyrosine kinase inhibitor sunitinib, a very promising agent that affects the proliferation of tumor cells with a p.R561C mutation in PDGFR-beta [31].

The case reported was particular because it associates some rare features: prenatally diagnosed solitary lesion in a female patient, with localization in the lower part of the body. We have systematized the cases identified in the literature by prenatal diagnosis, their features, treatment, and outcomes (Table A1).

\section{Conclusions}

IM is a differential diagnosis of soft tissue masses in early infancy and should be considered despite its low frequency and even if the typical characteristics are not met, like in the case presented. For diagnosis, the biopsy is mandatory, as treatment and prognosis 
depend on lesion characteristics such as clinical form (solitary or multicentric), location, and visceral involvement.

Author Contributions: S.P., D.A., O.B., D.B., I.S., and C.I.C. contributed equally in the conception and writing of this manuscript. All authors have read and agreed to the published version of the manuscript.

Funding: This research received no external funding.

Institutional Review Board Statement: The publication of this case report was approved by the Ethics Committee of "Sfânta Maria" Emergency Children Hospital (No. 31876/02.11.2021).

Informed Consent Statement: The data used in the article were permitted by the patient's legal guardian with consent for publication.

Acknowledgments: The authors express their gratitude to the Radiology and Imaging Department and Morphopathology Department (Doina Mihăilă).

Conflicts of Interest: The authors declare no conflict of interest.

\section{Appendix A}

Table A1. Cases with prenatal diagnsosis, their characteristics, management and outcome.

\begin{tabular}{|c|c|c|c|c|c|c|}
\hline PRef & $\begin{array}{c}\text { GA } \\
\text { (Weeks) }\end{array}$ & $\begin{array}{l}\text { Fetal Gender } \\
(\mathrm{M} / \mathrm{F})\end{array}$ & $\begin{array}{l}\text { Location \& } \\
\text { Size }(\mathrm{cm})\end{array}$ & $\begin{array}{l}\text { Prenatal Investigation } \\
\text { (Type \& Findings) }\end{array}$ & Management & Outcome Follow Up \\
\hline Nishioka, 1999 [32] & 37 & M & $\begin{array}{c}\text { Chest wall } \\
(5.0 \times 5.5 \times 2.5)\end{array}$ & $\begin{array}{l}\text { US: tumor recognized on } \\
\text { the chest wall. }\end{array}$ & $\begin{array}{l}\text { Resection and } \\
\text { skin graft at } \\
7 \text { days of life. }\end{array}$ & $\begin{array}{l}\text { No recurrence at } \\
11 \text { months. }\end{array}$ \\
\hline Kubota, 1999 [14] & 36 & $\mathrm{~F}$ & $\begin{array}{l}\text { Left upper arm } \\
\quad(8 \times 7 \times 5)\end{array}$ & $\begin{array}{l}\text { US: solid and spherical, } \\
\text { slightly inhomogeneous, } \\
\text { moderately echogenic } \\
\text { mass, well demarcated } \\
\text { with no evidence of } \\
\text { bone invasion. }\end{array}$ & $\begin{array}{l}\text { Resection of } \\
\text { tumor at } \\
2 \text { months } \\
\text { of age. }\end{array}$ & $\begin{array}{l}\text { No evidence of tumor } \\
\text { or functional disorder } \\
3 \text { years after surgery. }\end{array}$ \\
\hline Meizner, 2000 [15] & 30 & $\mathrm{~F}$ & $\begin{array}{c}\text { Paraspinal } \\
(4.2 \times 7.5 \times 3.5)\end{array}$ & $\begin{array}{l}\text { US }(30 \mathrm{w}) \text { : solid mass on } \\
\text { the left side of the spine } \\
\text { extending from T7 to L5 } \\
\text { of the vertebral column; } \\
\text { no Doppler blood flow. } \\
\text { MRI ( } 31 \mathrm{w}) \text { : well-defined } \\
\text { mass, no direct connection } \\
\text { between the mass and } \\
\text { spinal cord elements. }\end{array}$ & $\begin{array}{l}\text { Pregnanacy } \\
\text { termination } \\
(32 \text { w) via } \\
\text { fetocide } \\
\text { injection. }\end{array}$ & $\begin{array}{l}\text { On autopsy, a large } \\
\text { lump on the left side } \\
\text { of the spine, with no } \\
\text { connection to the } \\
\text { spinal canal. } \\
\text { Visceral involvement } \\
\text { was also noted in the } \\
\text { liver and } \\
\text { retroperitoneum. }\end{array}$ \\
\hline Wataganara, 2007 [33] & 35 & $\mathrm{~F}$ & $\begin{array}{l}\text { Anterior fetal } \\
\text { neck, extending } \\
\text { onto the } \\
\text { anterior chest } \\
\text { wall } \\
(10.8 \times 9.2)\end{array}$ & $\begin{array}{l}\text { US }(35 \mathrm{w}) \text { : homogeneous } \\
\text { solid mass. } \\
\text { MRI: in midsagittal plane, } \\
\text { a huge solid mass on the } \\
\text { anterior portion of the } \\
\text { neck and chest was } \\
\text { observed, with low signal } \\
\text { intensity mass. } \\
\text { Nasopharynx, } \\
\text { oropharynx, and trachea } \\
\text { intact and filled with } \\
\text { amniotic fluid position. }\end{array}$ & $\begin{array}{l}\text { Spontaneously } \\
\text { ruptured } \\
\text { membranes } \\
\text { at } 35 \text { weeks. } \\
\text { EXIT } \\
\text { procedure } \\
\text { Resection at } \\
11 \text { days } \\
\text { of age. }\end{array}$ & $\begin{array}{l}\text { At } 7 \text { months of age, } \\
\text { no signs } \\
\text { of recurrence. }\end{array}$ \\
\hline Muraoka, 2008 [20] & 32 & $\mathrm{~F}$ & $\begin{array}{l}\text { Spleen } \\
(5.7 \times 3.9)\end{array}$ & $\begin{array}{l}\text { US }(32 \mathrm{w}): \text { abdominal } \\
\text { tumor, } 5.7 \times 3.9 \mathrm{~cm} \text {; } \\
(34 \mathrm{w}) \text { : grown to } \\
6.0 \times 5.5 \mathrm{~cm} \text {. } \\
\text { MRI }(36 \mathrm{w}) \text { : left upper } \\
\text { abdominal tumor. }\end{array}$ & $\begin{array}{l}\text { Splenectomy } \\
\text { on day } 20 \\
\text { of life. }\end{array}$ & $\begin{array}{l}\text { No recurrence at } \\
3 \text { years of age. }\end{array}$ \\
\hline
\end{tabular}


Table A1. Cont.

\begin{tabular}{|c|c|c|c|c|c|c|}
\hline PRef & $\begin{array}{c}\text { GA } \\
\text { (Weeks) }\end{array}$ & $\begin{array}{l}\text { Fetal Gender } \\
(\mathrm{M} / \mathrm{F})\end{array}$ & $\begin{array}{l}\text { Location \& } \\
\text { Size }(\mathrm{cm})\end{array}$ & $\begin{array}{l}\text { Prenatal Investigation } \\
\text { (Type \& Findings) }\end{array}$ & Management & Outcome Follow Up \\
\hline Arabin, 2009 [18] & 13 & $\mathrm{~F}$ & $\begin{array}{l}\text { Superficial } \\
\text { head }\end{array}$ & $\begin{array}{l}\text { Monoamniotic twins. } \\
13 \mathrm{w} \text { : echodense tumor on } \\
\text { the side of one } \\
\text { twin's head. } \\
18 \mathrm{w} \text { : vascularization of } \\
\text { the tumor. } \\
30 \mathrm{w} \text { : intestinal dilatation } \\
\text { (same twin). } \\
\text { MRI: excluded } \\
\text { connections to the } \\
\text { ventricles or brain. }\end{array}$ & $\begin{array}{l}\text { Superficial } \\
\text { head tumor } \\
\text { resected and } \\
\text { laparotomy } \\
\text { for } \\
\text { abdominal } \\
\text { mass. }\end{array}$ & $\begin{array}{c}\text { Affected twin died } \\
\text { from sepsis } 12 \text { days } \\
\text { after birth; } \\
\text { Unaffected twin } \\
\text { normal at follow up. }\end{array}$ \\
\hline Yeniel, 2013 [34] & 32 & $\mathrm{~F}$ & $\begin{array}{l}\text { Left lung } \\
(4.6 \times 2.7)\end{array}$ & $\begin{array}{l}\text { US: solid mass detected in } \\
\text { the parenchyma of the left } \\
\text { lung; Color Doppler: } \\
\text { avascular. }\end{array}$ & $\begin{array}{l}\text { Thoracotomy } \\
\text { and complete } \\
\text { mass } \\
\text { resection on } \\
\text { day } 2 \text { of life } \\
\text { because of } \\
\text { respiratory } \\
\text { distress } \\
\text { syndrome. }\end{array}$ & $\begin{array}{l}\text { No recurrence or } \\
\text { symptoms } 1 \text { year } \\
\text { after surgery. }\end{array}$ \\
\hline Zhang, 2014 [17] & 38 & M & $\begin{array}{c}\text { Right side } \\
\text { paraspinal, a } \\
\text { pseudoulcerate } \\
\text { plaque } \\
(2.4 \times 2.2 \times 1.2)\end{array}$ & $\begin{array}{l}\text { US: mass on the fetal right } \\
\text { back (T3-8), hypoechoic } \\
\text { with sporadic hyperecho. } \\
\text { Color Doppler flow: } \\
\text { intermittent blood flow } \\
\text { inside and around } \\
\text { the mass. } \\
\text { MRI (next day after US): } \\
\text { normal result, with } \\
\text { no mass. }\end{array}$ & $\begin{array}{l}\text { Resection of } \\
\text { the mass } \\
3 \text { months } \\
\text { after birth. }\end{array}$ & $\begin{array}{c}\text { No recurrence at } \\
2 \text { years after surgery. }\end{array}$ \\
\hline Coleman, 2016 [35] & 29 & $\mathrm{~F}$ & $\begin{array}{c}\text { Posterior } \\
\text { medial aspect } \\
\text { of the left thigh } \\
\text { of her fetus } \\
(3.1 \times 3 \times 3.8 \\
\text { at } 29 \mathrm{w} ; \\
5.6 \times 4.8 \times 5.3 \\
\text { at } 33 \mathrm{w})\end{array}$ & $\begin{array}{c}\text { US }(29 \text { w): First } \\
\text { visualization. } \\
\text { US }(33 \text { w): Mass increased } \\
\text { in size, hypoechoic } \\
\text { compared to the adjacent } \\
\text { subcutaneous fat, but } \\
\text { isoechoic compared to } \\
\text { muscle. The underlying } \\
\text { bone was intact. } \\
\text { MRI (same day with the } \\
\text { last echo) defined the } \\
\text { mass as relatively } \\
\text { well-circumscribed, } \\
\text { superficial location that } \\
\text { replaced the medial } \\
\text { subcutaneous tissues of } \\
\text { the thigh. }\end{array}$ & $\begin{array}{c}\text { Surgical } \\
\text { excision on } \\
\text { hospital day } \\
5 \text { without } \\
\text { complication, } \\
\text { though it was } \\
\text { found to } \\
\text { involve the } \\
\text { investing } \\
\text { fascia of the } \\
\text { gracilis and } \\
\text { sartorius } \\
\text { muscles. No } \\
\text { direct } \\
\text { involvement } \\
\text { of the major } \\
\text { neurovascu- } \\
\text { lar } \\
\text { structures. }\end{array}$ & $\begin{array}{l}\text { No functional or } \\
\text { strength deficits in the } \\
\text { lower extremity at the } \\
\text { age of } 9 \text { months. }\end{array}$ \\
\hline Vemavarapu, 2017 [36] & 32 & $\mathrm{~F}$ & Left arm $(9 \times 5)$ & $\begin{array}{l}\text { US: well circumscribed } \\
\text { mass, arising from the left } \\
\text { arm, just beside the } \\
\text { humerus, but the osseous } \\
\text { structure normal; Color } \\
\text { Doppler: moderate blood } \\
\text { flow in the solid part of } \\
\text { the mass. } \\
\text { MRI: improvised the } \\
\text { detection and evaluation. }\end{array}$ & $\begin{array}{l}\text { Resection of } \\
\text { tumor. }\end{array}$ & $\begin{array}{l}\text { Normal upper } \\
\text { function and no } \\
\text { recurrence } 1 \text { year } \\
\text { after surgery. }\end{array}$ \\
\hline
\end{tabular}


Table A1. Cont.

\begin{tabular}{|c|c|c|c|c|c|c|}
\hline PRef & $\begin{array}{c}\text { GA } \\
\text { (Weeks) }\end{array}$ & $\begin{array}{l}\text { Fetal Gender } \\
(\mathrm{M} / \mathrm{F})\end{array}$ & $\begin{array}{l}\text { Location \& } \\
\text { Size }(\mathrm{cm})\end{array}$ & $\begin{array}{l}\text { Prenatal Investigation } \\
\text { (Type \& Findings) }\end{array}$ & Management & Outcome Follow Up \\
\hline Pekar-Zlotin, 2018 [37] & 34 & - & $\begin{array}{l}\text { Multiple } \\
\text { tumors }\end{array}$ & $\begin{array}{l}\text { US: multiorgan } \\
\text { involvement, with masses } \\
\text { predominantly in the } \\
\text { lower extremities, heart, } \\
\text { abdominal cavity, and } \\
\text { neck. Normal Doppler } \\
\text { studies in the major fetal } \\
\text { arterial and venous } \\
\text { circulations, as well as } \\
\text { normal amniotic fluid } \\
\text { volume and unremarkable } \\
\text { appearance of } \\
\text { the placenta. }\end{array}$ & $\begin{array}{l}\text { Inoperable } \\
\text { tumors. }\end{array}$ & $\begin{array}{l}\text { The infant died of } \\
\text { cardiac failure } 30 \text { days } \\
\text { after birth. }\end{array}$ \\
\hline Rekawek, 2019 [16] & 36 & M & $\begin{array}{c}\text { Lower thoracic } \\
\text { spine } \\
(3.5 \times 2.3)\end{array}$ & $\begin{array}{l}\text { US: avascular, } \\
\text { heterogeneous mass of } \\
\text { soft tissues, without cord } \\
\text { involvement. } \\
\text { MRI: thick-walled partly } \\
\text { cystic lesion in the right } \\
\text { paraspinal muscles of the } \\
\text { lower thorax. }\end{array}$ & $\begin{array}{l}\text { Biopsy on } \\
\text { day } 7 \text { of life. }\end{array}$ & $\begin{array}{l}\text { MRI at one year of } \\
\text { age: multiple soft } \\
\text { masses decreased in } \\
\text { size compared to } \\
\text { prior imaging, and } \\
\text { three additional } \\
\text { lesions: crus of the } \\
\text { left diaphragam, left } \\
\text { posterior chest wall, } \\
\text { and left shoulder. }\end{array}$ \\
\hline Evens, 2021 [38] & 33 & - & $\begin{array}{l}\text { Visceral organ } \\
\text { involvement } \\
\text { Lung masses }\end{array}$ & $\begin{array}{l}\text { US: dilated bowel loop. } \\
\text { MRI: suggested the } \\
\text { dilated loop of bowel was } \\
\text { colon, given the internal } \\
\text { high T1 signal compatible } \\
\text { with meconium. } \\
\text { Additionally, multiple, } \\
\text { solid-appearing lung } \\
\text { masses were noted, which } \\
\text { had not been previously } \\
\text { visualized on ultrasound. } \\
\text { After thorough review of } \\
\text { the MRI images of the } \\
\text { entire fetus, no primary } \\
\text { lesion was found. No } \\
\text { masses were visualized in } \\
\text { the extremities. }\end{array}$ & $\begin{array}{l}\text { The baby had } \\
\text { not passed } \\
\text { meconium } \\
\text { after } 1 \text { day of } \\
\text { life, therefor } \\
\text { an } \\
\text { exploratory } \\
\text { laparotomy: } \\
\text { nodules on } \\
\text { the bowel } \\
\text { serosa, } \\
\text { resulting in a } \\
\text { bowel } \\
\text { obstruction. } \\
\text { Owing the } \\
\text { visceral organ } \\
\text { involvement, } \\
\text { chemother- } \\
\text { apy was } \\
\text { considered; } \\
\text { however, it } \\
\text { was } \\
\text { ultimately } \\
\text { decided to } \\
\text { observe the } \\
\text { patient and } \\
\text { treat only if } \\
\text { there was } \\
\text { radiologic } \\
\text { progression } \\
\text { and/or } \\
\text { clinical } \\
\text { deterioration. }\end{array}$ & \\
\hline
\end{tabular}

\section{References}

1. Scheper, M.A.; DiFabio, V.E.; Sauk, J.J.; Nikitakis, N.G. Myofibromatosis: A case report with a unique clinical presentation. Oral Surg. Oral Med. Oral Pathol. Oral Radiol. Endod. 2005, 99, 325-330. [CrossRef] [PubMed]

2. Pelluard-Nehmé, F.; Coatleven, F.; Carles, D.; Alberti, E.M.; Briex, M.; Dallay, D. Multicentric infantile myofibromatosis: Two perinatal cases. Eur. J. Pediatr. 2007, 166, 997-1001. [CrossRef]

3. Venkatesh, V.; Kumar, B.P.; Kumar, K.A.; Mohan, A.P. Myofibroma-A rare entity with unique clinical presentation. J. Maxillofac. Oral Surg. 2015, 14 (Suppl. 1), 64-68. [CrossRef] 
4. NORD Rare Disease Database. Available online: https://rarediseases.org/rare-diseases/infantile-myofibromatosis/ (accessed on 1 November 2021).

5. Hausbrandt, P.A.; Leithner, A.; Beham, A.; Bodo, K.; Raith, J.; Windhager, R. A rare case of infantile myofibromatosis and review of literature. J. Pediatr. Orthop. B 2010, 19, 122-126. [CrossRef]

6. Stout, A.P. Juvenile fibromatoses. Cancer 1954, 7, 953-978. [CrossRef]

7. Kauffman, S.L.; Stout, A.P. Congenital mesenchymal tumours. Cancer 1965, 18, 460-476. [CrossRef]

8. Chung, E.B.; Enzinger, F.M. Infantile myofibromatosis. Cancer 1981, 48, 1807-1818. [CrossRef]

9. Smith, K.J.; Skelton, H.G.; Barrett, T.L.; Lupton, G.P.; Graham, J.H. Cutaneous myofibroma. Mod. Pathol. 1989, 2, 603-609.

10. Daimaru, Y.; Hashimoto, H.; Enjoji, M. Myofibromatosis in adults (adult counterpart of infantile myofibromatosis). Am. J. Surg. Pathol. 1989, 13, 859-865. [CrossRef]

11. Wu, W.; Chen, J.; Cao, X.; Yang, M.; Zhu, J.; Zhao, G. Solitary infantile myofibromatosis in the bones of the upper extremities: Two rare cases and a review of the literature. Oncol. Lett. 2013, 6, 1406-1408. [CrossRef]

12. Martignetti, J.A.; Tian, L.; Li, D.; Ramirez, M.C.; Camacho-Vanegas, O.; Camacho, S.C.; Guo, Y.; Zand, D.J.; Bernstein, A.M.; Masur, S.K.; et al. Mutations in PDGFRB Cause Autosomal-Dominant Infantile Myofibromatosis. Am. J. Hum. Genet. 2013, 92, 1001-1007. [CrossRef]

13. Stenman, G.; Nadal, N.; Persson, S.; Gunterberg, B.; Angervall, L. del(6)(q12q15) as the sole cytogenetic anomaly in a case of solitary infantile myofibromatosis. Oncol. Rep. 1999, 6, 1101-1104. [CrossRef]

14. Kubota, A.; Imano, M.; Yonekura, T.; Hirooka, S.; Nose, K.; Oyanagi, H.; Nakayama, M. Infantile myofibromatosis of the triceps detected by prenatal sonography. J. Clin. Ultrasound 1999, 27, 147-150. [CrossRef]

15. Meizner, I.; Shalev, J.; Mashiach, R.; Vardimon, D.; Ben-Raphael, Z. Prenatal ultrasound diagnosis of infantile myofibromatosis -A case report. Ultrasound Obstet. Gynecol. 2000, 16, 84-86. [CrossRef] [PubMed]

16. Rekawek, P.; Coleman, B.G.; Kamath, A.; Stone, J.L. Prenatal sonography of multicentric infantile myofibromatosis: Case report and review of the literature. J. Clin. Ultrasound 2019, 47, 490-493. [CrossRef] [PubMed]

17. Zhang, F.; Cheng, D.; Wu, M.; Ge, L.; Ma, X. Diagnosis of infantile myofibromatosis with pseudo-ulcerated plaque using prenatal ultrasound: A case report. Exp. Ther. Med. 2014, 8, 1769-1771. [CrossRef]

18. Arabin, B.; Hack, K.; Nooij, L.; Nikkels, P. Dis-crepant findings in a monoamniotic twin pregnancy affected by infantile myofibromatosis. Ultrasound Obstet. Gynecol. 2009, 33, 488-490. [CrossRef]

19. Alamo, L.; Beck-Popovic, M.; Gudinchet, F.; Meuli, R. Congenital tumors: Imaging when life just begins. Insights Imaging 2011, 2, 297-308. [CrossRef]

20. Muraoka, I.; Ohno, Y.; Kamitamari, A.; Okada, M.; Moriuchi, H.; Kanematsu, T. Congenital occurrence of solitary infantile myofibromatosis of the spleen. J. Pediatr. Surg. 2008, 43, 227-230. [CrossRef]

21. Thunnissen, B.T.; Bax, N.M.; Rövekamp, M.H.; Beek, F.J.; van Gorp, J. Infantile myofibromatosis: An unusual presentation and a review of the literature. Eur. J. Pediatr. Surg. 1993, 3, 179-181. [CrossRef]

22. Wiswell, T.E.; Davis, J.; Cunnigham, B.E.; Solenberger, R.; Thomas, P.J. Infantile myofibromatosis: The most common fibrous tumor of infancy. J. Pediatr. Surg. 1988, 23, 315-318. [CrossRef]

23. Koujok, K.; Ruiz, R.E.; Hernandez, R.J. Myofibromatosis: Imaging characteristics. Pediatr. Radiol. 2005, 35, 374-380. [CrossRef]

24. Fraitag, S.; Boccara, O. What to Look Out for in a Newborn with Multiple Papulonodular Skin Lesions at Birth. Dermatopathology 2021, 8, 390-417. [CrossRef]

25. Allen, P.W. The fibromatosis: A clinicopathologic classification based on 140 cases. Review articles, part 2. Am. J. Surg. Pathol. 1977, 1, 305-321. [CrossRef]

26. Fukasawa, Y.; Ishikura, H.; Takada, A.; Yokoyama, S.; Imamura, M.; Yoshiki, T.; Sato, H. Massive apoptosis in infantile myofibromatosis: A putative mechanism of tumor regression. J. Pathol. 1994, 144, 480-485.

27. Schmidt, D. Fibrous tumors and tumor-like lesions of childhood: Diagnosis, differential diagnosis, and prognosis. Curr. Top. Pathol. 1995, 89, 175-191. [PubMed]

28. Burton, J.L.; Lovell, C.R. Disorders of connective tissue. In Textbook of Dermatology, 6th ed.; Champion, R.H., Burton, J.L., Burns, D.A., Breathnach, S.M., Eds.; Blackwell Science: Malden, MA, USA, 1998; Volume 3, pp. 2048-2049.

29. Kiel, K.D.; Suit, H.D. Radiation therapy in the treatment of aggressive fibromatosis (desmoid tumors). Cancer 1984, 54, 2051-2055. [CrossRef]

30. Savasan, S.; Fulgenzi, L.A.; Rabah, R.; Mohamed, A.N.; Ravindranath, Y. Generalized infantile myofibromatosis in a patient with Turner's syndrome: A trial of interferon- $\alpha$. J. Pediatr. 1998, 133, 694-696. [CrossRef]

31. Sramek, M.; Neradil, J.; Macigova, P.; Mudry, P.; Polaskova, K.; Slaby, O.; Noskova, H.; Sterba, J.; Veselska, R. Effects of Sunitinib and Other Kinase Inhibitors on Cells Harboring a PDGFRB Mutation Associated with Infantile Myofibromatosis. Int. J. Mol. Sci. 2018, 19, 2599. [CrossRef] [PubMed]

32. Nishioka, K.; Seguchi, T.; Yamamura, Y.; Tatsumura, M.; Sou, H.; Gondo, T.; Hoshii, Y.; Iwata, T. Infantile myofibromatosis identified by fetal ultrasound. Br. J. Dermatol. 1999, 140, 539-541. [CrossRef]

33. Wataganara, T.; Ngerncham, S.; Kitsommart, R.; Fuangtharnthip, P. Fetal neck myofibroma. J. Med. Assoc. Thai. 2007, 90, 376-380. [PubMed]

34. Yeniel, A.O.; Ergenoglu, A.M.; Zeybek, B.; Kazandi, M.; Akercan, F.; Ozcan, C.; Veral, A. Prenatal diagnosis of infantile myofibromatosis of the lung: A case report and review of the literature. J. Clin. Ultrasound 2013, 41, 38-41. [CrossRef] [PubMed] 
35. Coleman, A.M.; Calvo-Garcia, M.A.; Zbojniewicz, A.M.; Alonso, M.; Lim, F.Y. Prenatal Diagnosis of Infantile Myofibroma with Postnatal Imaging Correlation. Fetal Diagn Ther. 2016, 40, 73-78. [CrossRef] [PubMed]

36. Vemavarapu, G.; Reddy, P.; Panigrahi, N.; Jayaram, H. Case Report of Prenatal Diagnosis of Fetal Left Arm Tumor (Infantile Myofibromatosis); The Fetal Medicine Foundation, 2017. Available online: https:/ fetalmedicine.org/abstracts/2017/var/pdf/ abstracts /2017/2057.pdf (accessed on 4 November 2021).

37. Pekar-Zlotin, M.; Levinsohn-Tavor, O.; Livneh, A.; Sher, O.; Melcer, Y.; Maymon, R. Gynecology and Oncology Fetal Myofibromatosis: A Challenge for Prenatal Diagnosis Mini Review of the English Literature. Obstet. Gynecol. Surv. 2019, 74, 607-610. [CrossRef] [PubMed]

38. Evens, A.; Gonzalez-Gomez, I.; Towbin, R.B.; Towbin, A.J.; Kucera, J.N. Infantile myofibromatosis: Prenatal and postnatal imaging features. Appl. Radiol. 2021, 50, 44-46. 